\title{
Incidence of Value Added Tax, Effects and Implications
}

\author{
George Obeng ${ }^{1,2}$ \\ ${ }^{1}$ University of Education, Winneba, Ghana \\ ${ }^{2}$ Faculty of Business Education, College of Technology Education Kumasi, Kumasi, Ghana \\ Correspondence: George Obeng, University of Education, Winneba; Department of Accounting Education, \\ Faculty of Business Education, College of Technology Education Kumasi, P. O Box 1277, Kumasi, Ghana. \\ E-mail: georgeobeng29@yahoo.com
}

Received: July 31, 2018

Accepted: September 4, 2018

Online Published: September 15, 2018

doi:10.5539/ijef.v10n10p52

URL: https://doi.org/10.5539/ijef.v10n10p52

\begin{abstract}
The current debate in the field of taxation and public finance is the concern of Value Added Tax (VAT) being inflationary and who the incidence or burden of payment falls. The implication from available literature and studies points to the fact that VAT can impact negatively on production and consumption, stifling free flow of economic activities. Literature is reviewed to find out the incidence of VAT and its implications on the firm and the consumer. It is established that VAT is not a cost to the business firm to make it inflationary but a charge independent of its pricing mechanism. It is also not extra cost to the consumer but part appropriation of the economic resource flow accruing to the consumer to settle the legitimate obligation of financing public expenditure. The paper concludes that the incidence of the tax is on the consumer and VAT is not inflationary but a means of tax optimality to stabilize the system in the event of market failure.
\end{abstract}

Keywords: economic resource flow, incidence of tax, inflationary, market failure, value added

\section{Introduction}

Concerns have been raised about the possibility of VAT being inflationary or impacting price increases as observed by (Euromonitor International, 2016; Chapman, 2001). The incidence of VAT either being on the firm or pass through to the consumer is also a concern to contributors to the debate. The debate gets attraction particularly at a time of first introduction or when there is the need to adjust the tax rate. However, there is little evidence of empirical work in the literature regarding the incidence of VAT and it being inflationary. Gaarder (2016) citing (Crawford, Keen, \& Smith, 1992) said the evidence base of the incidence of VAT or being inflationary is scarce. The incidence of the tax in an imperfect market environment could generate both over and under-shifting taxes to consumer prices (Gaarder, 2016, Seade, 1987; Delipalla \& Keen, 1992; Anderson, De Palma, \& Kreider, 2001; Besley \& Rosen). These challenges, misconception and misunderstanding of the impact of VAT have been a matter of discussion in many countries when VAT is to be introduced or the aftermath of the introduction.

Governments depend on taxes to meet public expenditure and other investment goals. It is the responsibility of government to carry on various projects to satisfy its objective of serving the interest of the citizenry and the other stakeholders and partners in development. The major interest of the citizenry and the other publics and development partners is the security and maintenance of socio-economic order. This responsibility imposed on and required of the Government goes with cost (Obeng, 2017a). The citizens are obliged to finance government expenditure and activities through the payment of taxes as imposed by their representatives in parliament. Governments mobilizing domestic revenue through taxes helps reduce budget deficits and the over reliance on loans and their dam consequences on the economy. It is therefore imperative for Governments to devise various means and strategies that identify economic activities with flow of measurable economic resources and returns to the citizens and legal persons for tax to be imposed thereon (Obeng, 2017a). One area gaining currency for mobilizing domestic revenue is value added in a given distribution chain to attract tax. Value Added Tax (VAT) is an indirect type of tax which is imposed on consumption or expenditure made by consumers for goods and services. VAT is one area explored to improve government domestic revenue and ensure optimality of the tax system. VAT was first introduced in France and according to Tait (1988) it is an unparalleled tax phenomenon. VAT which was associated with the European Union (EU) is now engaged by other governments in the other continents (Tait, 1988). VAT was introduced and adopted by countries due to the dissatisfaction of their existing tax structure and 
for efficiency in revenue mobilization (Tait, 1988).

This work is a review of relevant literature supported by theoretical models to find out the incidence of VAT, its effect on the cost of a product to the firm and the possibility to create inflation. The level and amount of the tax at each stage of the distribution chain absorbed in the price to the consumer (incidence) and in the event of market failure the reaction of the participants in the market. The paper is establishing the point that the incidence of VAT always fall on the consumer and VAT is neutrality of in pricing policy and decision of the firm. In the event of market imperfection and failure VAT can be used to optimize efficiency to the advantage of the consumer. The paper is in five sections scheduled as. Section one focusing on introduction. Section two examines the concept of value added, section three considers the effect of VAT on inflation, section four addresses the incidence of VAT,

section five examines VAT and the event of market failure, section six uses models to explains the effect of VAT on the Firm and Consumers in the event of Market Failure and finally section seven addresses the conclusion and recommendations of the study.

\section{The Concept of Value Added}

Value Added in the context of tax depicts output of human effort in the process of reshaping material inputs or economic resources in a given economic and production system to meet the taste and satisfaction of the consuming public who are prepared to offer a required reward. The human being as an economic agent has a given capacity to turn round available economic resources at his/her disposal to produce goods and services for consumption. The value created out of this effort is the summation of the input materials, the conversion cost of labour, production expenses and consumed part of capital assets (depreciation) and the required return or utility of the economic agent. The value added according to (Tait, 1988) is wages plus profit or output minus input. Capital expenditure does not form part of the value added except the part (depreciation) consumed during the period. Sales tax is on all business turnovers (Tait, 1988) and on capital expenditure. The consumable item may be required at different shapes, levels, location and purpose before it reaches and meets the satisfaction of the final consumer. In the process value is added through an effort and the agent adding the value expect a reward and the consumer is prepared to pay for the added value and reward at any given stage. Tax is then imposed on the value added at a given rate as the consumers' contribution to finance public expenditure (Obeng, 2017b). The tax paid at any stage (input VAT) in the distribution process is not transferable or form part of the cost to be incurred at the next stage but rather taken as credit (Kumar, 2012).

\section{VAT Effect on Inflation}

Value Added Tax (VAT) being inflationary means it will cause price rise in the distribution chain and affect the cost of production and distribution

With the expected introduction of VAT in 2018 in six (6) countries of Gulf Cooperation Council (GCC) which includes UAE, Saudi Arabia, Kuwait, Bahrain, Oman and Qatar similar concerns were raised (Euromonitor International, 2016).

Euromonitor International's Industry Forecast Model (IFM) suggested VAT to have significantly different impact on different consumer industries. The Industry Forecast Model (IFM) expressed the view that VAT is expected to raise consumer prices. It predicted that the introduction of five per cent (5\%) VAT across the GCC by January 2018 would lead to a fundamental change in the way businesses operate and will impact most consumer sectors, (Khaleej Times, 2017). The obvious and immediate impact of VAT is that production cost rises at each stage along the production process. At its best, the VAT only reduces the demand for each production stage. Tait (1988) in his study gave a summary of what he considered to be the fear expressed by persons opposing VAT as; regressivity of VAT, VAT as money machine, VAT being inflationary, intrusion of traditional preserve of authorities raising revenue and administrative nightmare.

Mukhopadhyay (2005) opined that if the inflationary impact is taken to mean a sustained increase in the rate of inflation then the concern would be conceptually misguided. The introduction of VAT, or any tax for that matter, can never, by itself, lead to a sustained increase in the rate of change in the price level. Such a change in the inflation rate can only be produced by an expansionary monetary policy under all circumstances. The impact of VAT after its introduction for the first time presented a case for study by Tait (1988). Tait (1988), as cited in Mukhopadhyay (2005) relying on the basis of International Monetary Fund data on VAT introduction for the first time in some countries found out in a survey that; VAT is never introduced in isolation, secondly a number of variables are influencing price change, and therefore, it is difficult to empirically assess the effect of VAT on prices and finally the impact of VAT on prices. It cannot therefore, be strictly segregated from the general trend in 
inflation (Tait, 1988 as cited in Mukhopadhyay, 2005).

Tait (1988) in the survey done in 22 countries expressed no major impact on the consumer price index. In another eight countries, the introduction of VAT was associated with a highly defined once and for all shifts in the consumer price index; only in one of the cases could establish accelerated rate of increase of the consumer price index. In seven other cases, although the shift was permanent there was no acceleration in the rate of change in prices attributable to VAT. The most important conclusion of the survey is that there seems to be nothing inherently inflationary about the use of VAT

Mukhopadhyay (2005) referring to other studies in the Netherlands and Indonesia saw the Central Planning Bureau in the Netherlands calculating the price effect of VAT from 1969 to 1980 and the trend in price rise due to VAT was clearly seen as insignificant, or none at all. In Indonesia, there was fear price rise before VAT was introduced in April 1985. Price indexes for consumer products fell slightly in the first week after adoption of VAT, and domestic inflation for the subsequent year was well below that for the previous year. Besley and Rosen (1999) in a study in some American cities find surprising variety of shifting patterns. They found that some commodities after tax prices increase by exactly the same amount of tax whiles others are over shifted- an increase in tax revenue.

VAT cannot be inflationary neither is it cascading. VAT replaced sales tax which had cascading effect that is tax on tax (Tait, 1988). VAT was introduced to replace, reduce or abolish existing tax considered to be nuisance and inefficient in mobilizing revenue for the state (Tait 1988). VAT varies with the value added at any stage of the distribution chain and takes a constant portion of that value. The business firm cannot in anyway influence the amount to be charged because it is a separate charge and not part of its operational cost.

\section{Incidence of VAT}

Tax incidence is concerned with the effect of taxation upon prices and profits (Delipalla \& Keen, 1998). The incidence of VAT is on the consumer. It is an appropriation of the consumers' income and not a charge on the profit of the business enterprise. The Mirrlees Review as cited by Gaarder (2016) affirms the position that the incidence of VAT is fully on consumer prices. The Mirrlees Review recommended in reform package to broaden the base for VAT in the UK by removing the zero rating for food (Atkinson, 2013).

Gaarder (2016) in a study in Norway examined the direct impact of the policy change on the consumer prices of food items as well as any cross-price effects on other goods found that taxes levied on food items are completely shifted to consumer prices, whereas the pricing of other goods is not materially affected.

Carbonnier (2007) (as cited in Gaarder, 2016) studies two VAT reforms in France which reduced the rates on new car sales and on housing repair services and his estimates suggest a majority of the tax burden is paid by consumers, especially in the competitive market for housing repair services.

VAT is introduced to ensure production efficiency, replace, reduce or abolish existing tax considered to be nuisance and inefficient in mobilizing revenue for the state (Tait, 1988). Business transactions on inputs or intermediate goods are not on target for VAT but the final consumer. The requirement of production efficiency proves to be a powerful one (Crawford, 2010). It is a key reason for the use of the VAT in preference to taxes that impact intermediate goods transactions (Crawford, 2010). VAT ensures a chain of output tax and input credit which remains unbroken, that no net revenue is collected from the taxation of intermediate goods sales so that the ultimate base of the tax is final consumption (Crawford, 2010).

Using Industry Forecast Model (IFM) price elasticity to evaluate VAT impact on consumer price, Euromonitor International (2016) opined that the impact of price increase on volume sales is generally negative, but the impact of price increase on value sales can be either positive or negative depending on how elastic category sales are. When category price elasticity is low (category is price-inelastic), price increase leads to a value sales growth, as the decline in volume sold is lower than the increase in price in relative terms. In the case of price-elastic categories, the decline in volume will be larger than the increase in price, which will lead to a decline in revenues.

Price elasticity and are parallel. VAT is a separate charge only on the value added and not cost or charge to the business or person adding value. The volume of VAT depends on the value in the production process in a multi stage chain of distribution and consumption of a good or service. It is also not part of the pricing decision of the person and therefore cannot have effect on any competition among businesses in the perfect market. VAT is a proportional charge on value added which is determined by the business and therefore VAT is neutral in the market scheming of competing firms. Firms continue to have a level of equal playing field after introduction of VAT. Any change in consumer price either positive or negative in addition to VAT should lie at the door steps of the affected businesses to check their internal operational efficiencies. Any absorption by or incidence of VAT on any firm may 
be the results of compensating consumers of inefficiencies passed on to consumers in a competitive market. This then manifests a market failure on the part of the firm behaving as if operating as a monopoly

Kosonen (as cited in Gaarder, 2016) analyze the incidence of VAT in the context of hairdressing services in Finland. His findings and estimates suggest that the tax burden on hairdressing services is shared between consumers and producers. In this case the burden of analyzing the reasons for this incidence of the tax and allocating part on the hairdressing firms is not attributable to VAT. The problem should lie with the firms and their internal efficiencies (Gaarder, 2016; Seade, 1987; Delipalla \& Keen, 1998; Anderson, De Palma, \& Kreider, 2001).

\section{VAT and Market Failure}

Governments have the responsibility to enact laws to control the behaviour of individual members of society to ensure some level of equity, peace and harmony. Individual private members of society carry on various economic activities motivated by their self interest. Their major objective is to make profit at the expense of others and the society if not checked. In the free market system the price mechanism or the invisible hand of demand and supply ensures efficiency in production and the distribution of resources. Delipalla and Owen (1998) opined that since perfectly competitive firms earn zero profits, under perfect competition there is only a price effect. In the free market there is competition whereby participants cannot control the market except the price bidding offered by the market. Consumer prices increase by just the amount of the tax if the long run supply curve is horizontal, and by less than that if it is upward sloping (Delipalla \& Owen, 1998). Price rising by more than the amount of the tax may indicate imperfection of the system a situation that is not a possibility in perfect competition (Delipalla \& Owen, 1998). If the system worked perfectly there would be no market failure (Slavin, 2002). When resources are not allocated efficiently there is market failure. Market failure may be caused by externalities that are cost or have negative impact on members of society who have no control on the actions of those committing the act. Market failure could occur in monopoly or oligopoly instances (Slavin, 2002). In such cases the price mechanism is broken down (Eaton, Eaton, \& Allen, 2005). In situations of information asymmetry and uncertainties consumers may not have the needed informed knowledge to make decisions and good choices (Eaton, Eaton, \& Allen, 2005). Uncertainty of information may distort business transactions and the market will fail to make maximum gains from trade (Eaton et al., 2005). In other cases where tax charge affects intermediate goods it will negatively impact on prices and be inflationary. This could lead to production inefficiency (Crawford, 2010). There is the need for production efficiency and for this reason the use of VAT is considered to be of preference to taxes that impact intermediate goods transactions (Crawford, 2010). For the reason of production efficiency and allocation of resources and limiting the factors of externalities and market failure government collects taxes, provide services and issues regulations (Slavin, 2002) to control the economy. VAT that does not affect intermediate goods but charges the final consumer (Crawford, 2010) is a best tax strategy for maintaining the price mechanism and ensuring perfect competition in the business environment. The instance of VAT is at the advantage of the consumer provided there is perfect competition. The introduction of VAT by governments should not only be motivated and at the consideration of revenue but to protect the price mechanism of the market to the benefit of the consumer.

\section{Effect of VAT on the Firm and Consumers and Market Failure}

The following sections consider two models used to address the effect of VAT on the business firm and the consumer at the market place. The first model gives impetus to the pricing mechanism of the business and its relation with VAT. The model depict that VAT charge is separate from management pricing policy. This should allay the fears of businesses and other stakeholders concerns of VAT being inflationary and influence on supply and demand. The second model on the other hand posits that consumers pay tax as an appropriation of their income and not appropriation of profit. Citizens are obliged to finance the government they put in place to rule over them to ensure security and equal opportunities (Obeng, 2017b). They owe a responsibility to ensure security of the state and its environments the cost of which is for the citizens to pay. We shall see that members of society are to exact part of their resources to finance public expenditure for no valuable consideration. This confirms one of the cardinal principles of tax that tax does not offer direct benefit to the taxpayer. For this reason members of society appropriate their economic resource flow between themselves and the state.

\subsection{MODEL 1 VAT Incidence and the Firm}

In this three plane model made up of price, quantity and cost, the focus is on how VAT impact on firms' pricing policy and the effect on consumers. 
Tax (VAT) Effect on Firms

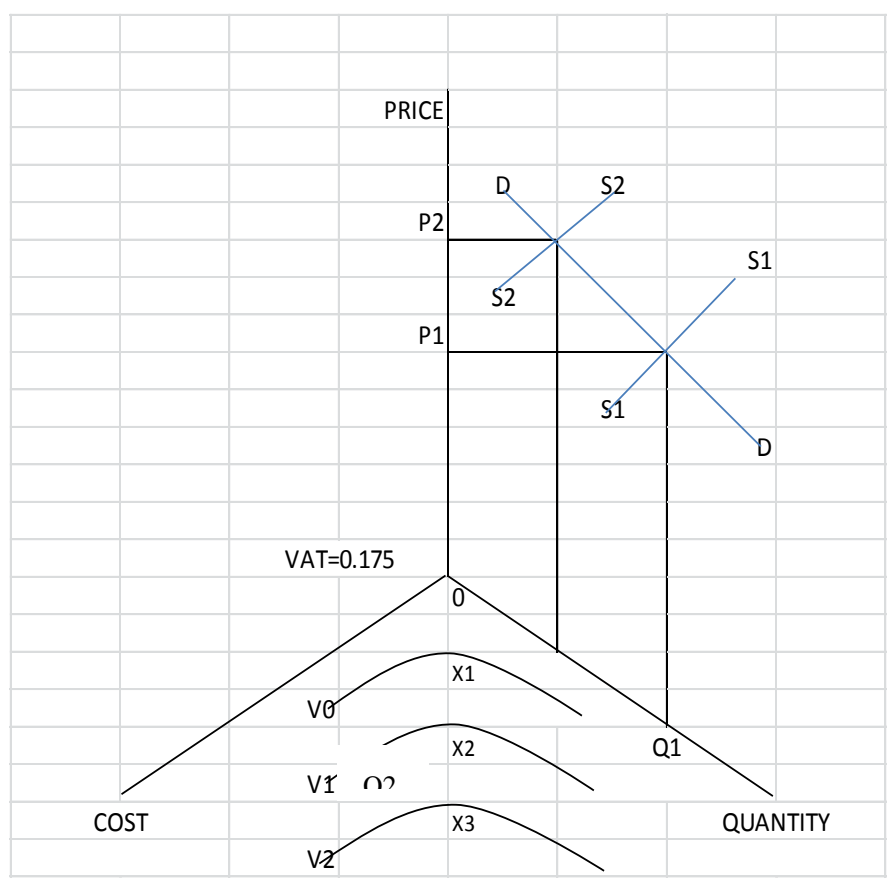

Figure 1. VAT Incidence and the firm

\subsubsection{Assumptions Underlying the Model}

The model is derived based on the following assumptions.

There is a perfect market and firms are price takers.

There is a linearity of the Variables; VAT Rate, Price/value added and Total cost.

Firms have defined cost zone of efficiency to operate in.

VAT (Tax) is a charge on price (value added) and not cost to the firm.

The consumer has accepted the value added by the firm and prepared to pay for it.

VAT is a function of Price and as price or value added increases VAT goes up and when price or value added decreases VAT declines

\subsubsection{The Model and Implications}

If price or value added is zero VAT is zero; curve V0 and total cost payable by the consumer is X1 made up of the price of the product and VAT of zero $(\mathrm{P}+\mathrm{V} 0)$

If price or value added moves to level P1 demand and supply establish equilibrium for the firm's quantity to be demanded and supplied at P1 and S1. VAT is then charged and paid at V1, separately from the firm's revenue and the consumer pays for the total cost made up of price (P1) of the product and VAT (V1) and total cost is X2 (P1 + $\mathrm{V} 1$ ). If supply reduces to line $\mathrm{S} 2$ price increases to $\mathrm{P} 2$, VAT revenue increases to $\mathrm{V} 2$. Total cost to the consumer is $\mathrm{X} 3$, P2 plus V2. If quantity of the product supply increases from S2 to S1, demand falls, price and value added also falls to P1, VAT revenue reduces as well. The cost of the business operations is established to be separate from VAT which is a charge to the consumer. The VAT is not part of the pricing policy of the firm. The firm in establishing its price to be charged on its products should consider all factors that may affect its competitiveness at the market place. Price elasticity and its negative effect on demand and supply as posited by (Euromonitor International, 2016 and Investopedia, 2015) to be the cause of VAT cannot be tenable.

Delipalla and Keen (1998) opined that since perfectly competitive firms earn zero profits, under perfect competition there is only a price effect. They contended that consumer prices increase by just the amount of the tax if the long run supply curve is horizontal, and by less than that if it is upward sloping. Price rising by more than the amount of the tax is not a possibility. Any change in demand or supply of any product should be the concern of management internal information systems and should not be attributable to the consequence of the introduction of VAT. The VAT is a fixed charge with equal or proportional effect and cannot be discretional to the 
one bearing the burden of payment. In this regard once the consumer accepts the product to satisfy his interest or utility values he sees the price offering as equal the value he is paying for. The incidence of VAT on the consumer as revealed by (Gaarder, 2016; Mukhopadhyay 2005), cannot be void so long as the internal efficiencies of the firm are in order.

If at any time the tax charge of a product to the consumer moves away from any of the indifference curves of V0, V1 and V2 as established at the market place, then there is cause for alarm. The firm with that product may have problem with its internal operations and efficiencies that may cause its operational cost and value added to be higher than the industry or system standard (Gaarder, 2016; Seade, 1987; Delipalla \& Keen, 1998; Anderson, De Palma \& Kreider, 2001). The firm may have to absorb part of the VAT to be at equilibrium with other firms or risk kick out of business. If the model represents the industry or the economic system (market) then any shift outside the cost curves implies that consumers are spending outside and beyond their budget and acceptable cost of the product, they are over stretched and being rational they may switch. Secondly there is a system or market failure with firms being inefficient in handling available resources. Expecting consumers to pay for such inefficiencies would not be feasible. There cannot be any shift in terms of demand and supply at the market place to the advantage or disadvantage of any product and their substitutes with the introduction of VAT. However, it should be anticipated that consumers will react initially to the VAT at first introduction that add to their bills the extra tax. The reaction will not take long for the consumer to adjust for the market to assume normalcy. The timing to adjust and level up at the prevailing price and cost may depend on different variables (Tait, as cited in Mukhopadhyay, 2005) including; the type of product, markets, the consumers and their income levels and budget. For the firm it has to improve its internal operations to reduce cost to the market acceptable standard or risk pushed out of the market by competitors. This problem at the market level attests to market or system failure. There could be a government expansionary monetary policy, with payments not supported by production. The system becomes inflationary and government intervention should prevail by using the tax system to absorb the excesses. VAT then is not causing inflation but as catalyst controlling inflationary pressures in the system. VAT should achieve optimum revenue for the state as such it works better in perfect competition market (Atkinson, 2013). In the absence of this any sign of monopolistic prevalence can be controlled through VAT

\subsection{VAT Incidence Model 2}

Tax (VAT) Effect on the Consumer

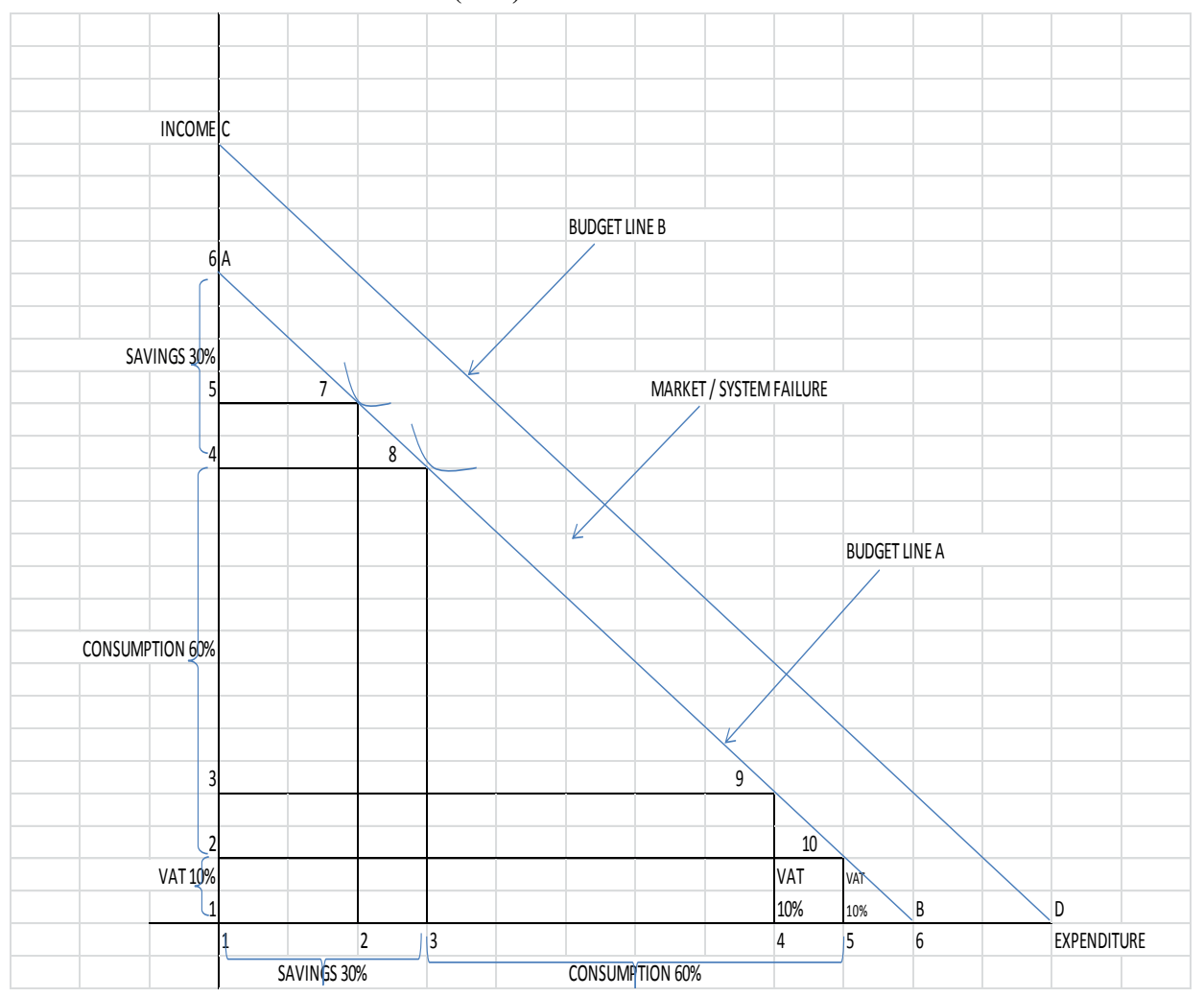

Figure 2. Consumers incidence of tax and appropriation of economic resource flow 


\subsubsection{Assumptions}

There is a perfect market and firms are price takers.

There is a linearity of the Variables; VAT Rate, Price/value added and Total cost.

Consumers have defined level of income as his budget at any given time.

VAT (Tax) is an appropriation of income.

The consumer has accepted the value added by the firm and prepared to pay for it.

\subsubsection{The Model and Implications}

The model depicts a consumer with income and budget in relative terms $100 \%$ on line $\mathbf{A B}$.

At any giving time the consumer's income equates his expenditure.

The income is appropriated for VAT (Tax), Consumption and Savings.

The $\mathrm{X}$ axis represents Expenditure and $\mathrm{Y}$ axis for Income.

In the first case there is a VAT of $10 \%$ marked as 5, 6 and 10, on the $\mathrm{X}$ axis $(1,2,6$ and 10 on the $\mathrm{Y}$ axis) consumption of $60 \%$ marked as 3, 5, 8 and 10 on the $X$ axis (2, 4, 8 and 10 on the $Y$ axis). Savings of $30 \%$ marked as $1,3,4$, and 8 on the $\mathrm{X}$ axis $(4,6$, and 8 on the $\mathrm{Y}$ axis).

If VAT is increased by $10 \%$ to $20 \%$ marked 4,6 and 9 on the $\mathrm{X}$ axis $(1,3,6$ and 9 on the $\mathrm{Y}$ axis), the consumer as rational being will prefer to maintain his ego and satisfaction in consumption level of $60 \%$ marked 2, 4,7 and 9 on the $\mathrm{X}$ axis $(3,5,7$ and 9$)$ and reduce his savings by $10 \%$ and save $20 \%$ marked 1, 2, 5 and 7 on the $\mathrm{X}$ axis $(5,6$ and 7 on the $\mathrm{Y}$ axis).

By appropriating the income for tax, consumption and savings, any amount left over, the consumer is indifferent at points 7 and 8 when he has appropriated his income to pay for his tax and consumption and is having the best satisfaction he can dream of. As tax and consumption expenditure increase the consumer will do away with savings.

At any event when total of VAT and consumption exceeds the budget line AB; it may depict system failure and inefficiencies in the system. The consumer has to cut down pleasure and work more, earn more to be on line CD. Firms may be inefficient in their production system with high cost which may force them to review operational cost and be efficient or absorb part of the VAT/Tax to stay in business. Government may be inefficient and in expansionary monetary policy not supported by production, a sign of system/market failure. It may call for austerity measures with higher taxes. The government then puts in place social mitigation policies to support production and reduce such operational inefficiencies through taxes.

VAT or tax should not be seen as an expense deductible before deriving profit, neither should it be appropriation of profit. It is an appropriation of income or economic resource flow of the tax payer. The income in principle is the total economic resource flow and not net profit after taken from the income all allowable deductions. Income tax as a direct tax allows some thresholds and deductions, as part value added, to be made from income derived by certain categories of persons, particularly corporate entities, before taxes are imposed. The corporate entity and business can shift and transfer the tax to the consumer in imperfect markets but not in competitive markets. VAT considers volume of activity but it is not additional cost to the tax payer or consumer because no deductions are allowed on the value added. Tax is always an appropriation of measurable economic resource flow or income and not a cost or expense to be taken from profit. A historical account to support this is when people from some cultures appropriate their produce or income from their economic activities as tax to the palace. In Ghana in the Akan communities subjects appropriate farm produce and catch made in hunting to their chiefs and Kings. Reference to the bible as any book of research also saw the Israelites appropriating a tenth of their economic resources to their leaders. This principle is strictly upheld when it comes to indirect taxes. The consumer's budget or income as the total economic resource flow at any given time is appropriated to cover expenditure on consumption for goods and services, tax and savings if any. The consumer is indifferent and motivated by the satisfaction to be derived from his preference ordering and not by any other factor like cost. If firms are price takers in a competitive market and VAT being a flat rate then final cost to the consumer should relatively be the same for a product offered in the market. There cannot be any change in price occasioned by VAT to increase the cost of a product to the extent of affecting the demand and supply of the product. In effect substitution of any product orchestrated by increase in cost of the product due to VAT is not feasible in both the short and long run. Attesting to this is Gaarder (2016) study which concluded that VAT on food items is completely shifted to consumer prices, implying that producers bear little, if anything, of the tax burden. 
In the budget and economic resources framework of the consumer, if the amount earmarked for consumption and expenditure on goods and services is not sufficient enough to meet his/her demands because of the tax, the consumer, in the short term and temporarily, may adjust his consumption pattern by; reducing the quantity of goods and services needed, or adjusting and reducing his/her savings to satisfy the consumption needs or ensure productivity of his/her available resources. This will pave way for the consumer to meet his/her budget.

\section{Conclusion and Recommendations}

We have considered value added tax (VAT), an indirect tax imposed by Government to raise enough domestic revenues in running the affairs of a country. Taxes are also used to control the socio economic environment and ensure equilibrium in the scheme of affairs.

Concerns are raised about the effect of VAT on economic activities to the extent that it can cripple the market demand and supply of goods and services, and faces strong resistance when it is initially introduced. This study reviewed some of these concerns, the fear and implications of VAT with the objective of to find out,

a. If consumers will pay more than necessary or VAT being inflationary.

b. The incidence of VAT.

c. Market failure and Government position and policy direction of VAT.

It is established that where there is a constant VAT rate at all stages of the distribution process the VAT charged is constant on the total value added. The VAT as calculated is then added to the price charged to get the total cost to the consumer. Prices of the products are not affected as VAT paid earlier as input VAT is not added to the price or cost of the product before output VAT is calculated. It is the amount of value added that determines the tax to be added and not the price charged by the business enterprise. The input VAT is a credit claim by the business and not part of the cost of the product in calculating output VAT. Therefore VAT is not inflationary. VAT not being inflationary is affirmed by Mukhopadhyay (2005) who opined that if the inflationary impact is taken to mean a sustained increase in the rate of inflation then the concern would be conceptually misguided.

The business enterprise charges VAT on the value added which the consumer accepts to pay. The value added according to Tait (1988) is wages plus profit or output minus input. Capital expenditure does not form part of the value added except the part (depreciation) consumed during the period. The business firm cannot in anyway influence the amount to be charged because it is a separate charge and not part of its operational cost.

The incidence of VAT is on the consumer (Mukhopadhyay, 2005). Tax incidence is concerned with the effect of taxation upon prices and profits (Delipalla \& Keen, 1998). VAT is an appropriation of the consumers' income and not a charge on the profit of the business enterprise. The Mirrlees Review as cited by Gaarder (2016) affirms the position that the incidence of VAT is fully on consumer prices.

In an imperfect market the business can price products with undue abnormal profits as value added and charge VAT yet the incidence of VAT will be borne by the consumer. However, in the perfect market any abnormal profit or internal inefficiencies pushed to the consumer will be rejected by the market. The inefficiencies will be exposed by the high price after VAT and this will affect the market of the business. This will compel the business to absorb part of the tax with its abnormal profit or risk pushed out of business.

VAT does not impact on the cost of intermediary goods of the firm which ensures efficiency for firms to operate on equal level field. This proves to be a key reason for the use of the VAT in preference to taxes that impact intermediate goods transactions (Crawford, Keen, \& Smith, 2010).

It is recommended that Government through the tax system checks businesses and control the expansionary monetary policy to ensure equilibrium in the socio-economic environment. Any cash flow into the system that is not supported by production could have inflationary pressures on the system/market. VAT can then be used to mob up the excess cash flow to maintain equilibrium. Optimum tax then becomes feasible as advocated by the Mirrlees review on the British tax system.(Atkinson, 2013) in a noncompetitive market where the market is dominated and controlled by few and large firms in the market.

\section{Acknowledgements}

My sincere gratitude goes to Dr. Dadson Awunyo Vitor of Kwame Nkrumah University of Science and Technology, Department of Agricultural Engineering for his painstaking efforts in reading through the manuscript and the rich suggestions made to improve this work. I also have the pleasure to thank Mr. Alfred Morrison of University of Education, Winneba, Accounting Studies Education, Kumasi Campus for his extra-ordinary support and my daughter Martina Obeng Takyi for staying with me all the time in preparing my papers. Finally I wish to extend my appreciation to the reviewers of this paper, the editorial staff and other 
employees of the International Journal of Economics and Finance for making the publication of this paper possible.

\section{References}

Atkinson, T. (2013). The "Mirrlees Review" of UK Taxation. Royal Economic Society. Newsletter, 160, 5-6.

Besley, T. J., \& Rosen, H. S. (1999). Sales Taxes and Prices: An Empirical Analysis. National Tax Journal, 52(2), 157-178.

Carbonnier, C. (2007). Who Pays Sales Taxes? Evidence from French VAT reforms, 1987-1999. Journal of Public Economics, 91, 1219-1229. https://doi.org/10.1016/j.jpubeco.2006.12.004

Carbonnier, C. (2013). The Incidence of Non-Linear Consumption Taxes. Working Papers halshs-00872474, HAL.

Chapman, E. (2001). Introducing a Value Added Tax : Lessons from Ghana. PREM Notes; No. 61. World Bank, Washington, DC. Retrieved from https://openknowledge.worldbank.org/handle/10986/11360

Crawford, I., Keen, M., \& Smith, S. (2010). Value Added Tax and Excises. In J. Mirrless, S. Adam, T. Besley, ... \& J. Poterba (Eds.), Dimensions of Tax Design, The Mirrlees Review (chap. 4, pp. 275-422). New York: Oxford University Press Inc.

Delipalla, S., \& Keen, M. (1998). The Comparison between Ad Valorem and Specific Taxation under Imperfect Competition, Evidence from the European cigarette industry. Journal of Public Economics, 49, 351-367. https://doi.org/10.1016/0047-2727(92)90073-O

Eaton, C. B., Eaton, F. D., \& Allen, W. D. (2005). Microeconomics theory with applications (6th ed., p. 665). Pearson Prentice, Torontoss.

Gaarder, I. (2016). Incidence and Distributional Effects of Value Added Taxes (pp. 2-4 \& 30). https://doi.org/10.2139/ssrn.2784559

How does a value added tax (VAT) impact the stages on production - Investopedia. Retrieved from http://www.investopedia.comask/answers

John, I. (2017). How VAT impacts business, consumers; consumers may pay more in real estate, retail, telecom, IT sectors. Khaleei Times.

Kumar, A. (2012). The cascading effect of taxation; what do we understand by it? Business and Economy.

Mukhpadhyay, S. (2005). Does VAT lead to inflation.

Obeng, G. (2017a). Public sector accounting and financial management. Kumasi, Benson Print.

Obeng, G. (2017b). Goodwill Taxation. Kumasi, Benson Print.

Slavin, L. S (2002). Economics (6th ed., pp. 90-94). McGraw-Hill Irwin, Boston.

Tait, A. A. (1988). Value added tax international practice and problems. International Monetary Fund, Washington D.C.

The impact of the 2018 value added tax (VAT) on the food and drink industry in UAE and Saudi Arabia. Euromonitor International.

\section{Copyrights}

Copyright for this article is retained by the author(s), with first publication rights granted to the journal.

This is an open-access article distributed under the terms and conditions of the Creative Commons Attribution license (http://creativecommons.org/licenses/by/4.0/). 